\title{
Sebuah Upaya Mempertahankan Identitas Nasional: Pelestarian Indegenous Knowledge melalui Pengembangan Teknologi pada Perpustakaan Nasional
}

\author{
Anton Hermawan \\ anton.hermawan@staff.uksw.edu
}

\begin{abstract}
Abstrak
Jika melihat dari jenisnya, ada beberapa jenis perpustakaan, antara lain perpustakaan sekolah, perpustakaan universitas, perpustakaan pribadi, perpustakaan nasional, dsb. Perpustakaan sekolah menyajikan produk terkait dengan pendidikan sekolah dasar sampai SMA, perpustakaan universitas menyajikan produk yang terkait dengan pendidikan di bangku kuliah, perpustakaan pribadi menyajikan bahan bacaan yang disukai yang mencerminkan kepribadiannya, sedangkan perpustakaan nasional seharusnya menyajikan produk-produk yang mencerminkan negara tersebut.

Sejarah sebuah bangsa yang besar akan bisa dilestarikan dari generasi ke generasi melalui perpustakaan nasional. Indonesia dikenal sebagai negara yang memiliki indegenous knowledge (kearifan lokal) serta kekayaan budaya yang besar dan tersebar dari sabang sampai merauke. Selayaknya kearifan lokal serta kekayaan budaya yang dimiliki tersebut dapat dikoleksi didalam sebuah perpustakaan.

Melalui perkembangan teknologi informasi, pengembangan perpustakaan menjadi sebuah jawaban agar koleksi kearifan lokal dan kekayaan budaya tersebut dapat diakses oleh bangsa Indonesia dari sabang sampai merauke dengan harapan mampu memperkuat serta mempertahankan identitas nasional Indonesia. Namun sejalan dengan pengaruh globalisasi dan kemajuan teknologi,semakin terindikasi adanya ancaman terhadap lunturnya kearifan lokal dikalangan generasi penerus. Oleh karena itu, dibutuhkan manifestasi baru agar perpustakaan nasional menjadi hal yang menarik untuk diakses dan ditelusuri oleh generasi muda penerus bangsa, agar identitas nasional tetap dapat dipertahankan. Salah satunya adalah dengan mengembangkan perpustakaan melalui teknologi yang akan memberikan pengalaman yang lebih menarik terhadap "petualangan pemustaka" ketika menelusur sebuah perpustakaan.
\end{abstract}

Kata kunci: perpustakaan, perpustakaan nasional, indegenous knowledge (kearifan lokal), identitas nasional. 


\begin{abstract}
Abtract
If you look at the type, there are several types of libraries, including school libraries, university libraries, private libraries, national libraries, etc. School libraries present products related to elementary to senior high school education, university libraries provide products related to college education, private libraries provide the preferred reading material that reflects their personality, while the national library should present products that reflect the country.

The history of a great nation will be preserved from generation to generation through the national library. Indonesia is known as a country that has indegenous knowledge and great cultural wealth and spread from Sabang to Merauke. Just as well as indegenous knowledge and cultural wealth owned can be collected in a library.

Through the development of information technology, library development becomes an answer so that the collection of indegenous knowledge and cultural wealth can be accessed by the Indonesian nation from Sabang to Merauke in the hope of strengthening and maintaining Indonesia's national identity. But in line with the influence of globalization and technological progress, the more indication of threats to the dissolution of indegenous knowledge among the next generation. Therefore, a new manifestation is needed to make the national library interesting to be accessed and traced by the younger generation of the nation, so that the national identity can be maintained. One way is to develop libraries through technology that will provide a more interesting experience with "readers adventures" when searching for a library
\end{abstract}

Keywords: library, national library, indegenous knowledge,national identity.

\title{
Latar Belakang
}

Kata perpustakaan bukan merupakan hal yang asing lagi ditelinga sebagian besar orang.Perpustakaan sudah menjadi sarana pendidikan, pelestarian budaya, penelitian bahkan sekarang sebagai tujuan wisata murah. Melihat perkembangan dan fungsi perpustakaan di Indonesia khususnya dalam pelestarian budaya, hal ini tidak dapat dipisahkan dengan perkembangan dan sejarah perpustakaan di belahan negara lain.

Jika melihat sejarah mula-mula mengenai berdirinya perpustakaan, diperoleh fakta bahwa ada keterkaitan antara budaya dan perpustakaan yang sudah dikenal sejak 3000 tahun yang lalu (Suwarna, 2007: 23).Hal ini ditunjukkan dengan ditemukannya salinan rekening, jadwal kegiatan pengetahuan yang ditulis dalam bentuk lempeng tanah liat oleh bangsa Sumeria. Kemudian setelah ditaklukkan oleh Babylonia, diadopsilah 
kebudayaan Sumeria dimana didalamnya terdapat kepercayaan, praktik keagamaan dan tulisan Sumeria.Hal ini juga terjadi pada jaman Mesir peradaban, ketika ditemukannya tulisan hieroglyph yang digunakan bangsa Mesir untuk menulis pesan terakhir dimonumen untuk mengagungkan Raja.Sedangkan pada jaman Yunani, ditemukan tulisan mycena (1500 SM), yang kemudian dikembangkan menjadi 26 aksara seperti yang kita kenal saat ini.Yunani mengenal perpustakaan sekitar abad ke-6, Filsuf Aristoteles dianggap sebagai orang yang pertama kali mengumpulkan, menyimpan dan memanfaatkan budaya masa lalu.

Dari uraian diatas dapat disimpulkan bahwa berdirinya perpustakaan tidak lepas dari upaya sebuah negara dalam mengkoleksi budayanya, dengan tujuan pelestarian agar nantinya dapat diturunkan dan dipelajari bagi generasi berikutnya. Melalui perkembangan teknologi informasi, saat ini telah terjadi peralihan perpustakaan tradisional menuju era perpustakaan digital, walau jika dicermati hal ini tidaklah cukup untuk melestarikan budaya. Oleh karena itu, penulis tertarik untuk mengkaji bagaimana manifestasi perpustakaan yang dimungkinkan mampu menarik generasi penerus untuk tetap melestarikan budaya Indonesia khususnya kearifan lokal (indegenous knowledge).Selain itu, bagaimana dampaknya terhadap identitas nasional bangsa Indonesia, yang dikenal memiliki kekayaan budaya yang ber Bhineka Tunggal Ika.

\section{Masalah Penelitian}

1. Bagaimana manifestasi perpustakaan nasional dalam melestarikan indegenous knowledge?

2. Apa dampak dari manifestasi perpustakaan digital (nasional) tersebut terhadap indentitas nasional?

\section{Tujuan}

1. Mengetahui manifestasi apa saja yang mungkin dapat dilakukan perpustakaan nasional dalam melestarikan indegenous knowledge. 
2. Untuk mengetahui dampak dari manifestasi perpustakaan digital (nasional) terhadap identitas nasional.

\section{Tinjauan Pustaka}

\section{Indigenous Knowledge}

Jika mengacu pada UNESCO (dalam Laksmi, 2007), indigenous knowledge didefinisikan sebagai praktik, representasi, ekspresi, pengetahuan, ketrampilan, termasuk instrumen, objek, artefak dan ruang kebudayaan yang dikenal oleh suatu komuniti, kelompok atau individu-individu.

Dalam wikipedia disebutkan bahwa, kearifan lokal merupakan bagian dari budaya suatu masyarakat yang tidak dapat dipisahkan dari bahasa masyarakat itu sendiri. Kearifan lokal biasanya diwariskan secara turun temurun dari satu generasi ke generasi melalui cerita dari mulut ke mulut.Kearifan lokal sebagai suatu pengetahuan yang ditemukan oleh masyarakat lokal tertentu melalui kumpulan pengalaman dalam mencoba dan diintegrasikan dengan pemahaman terhadap budaya dan keadaan alam suatu tempat.Kearifan lokal ini biasa ditemukan dalamcerita rakyat, peribahasa, lagu, dan permainan rakyat.

Semetara itu jika melihat definisi kearifan lokal dari UU No. 32 Tahun 2009, dikatakan bahwa kearifan lokal adalah nilai-nilai luhur yang berlaku dalam tata kehidupan masyarakat untuk antara lain melindungi dan mengelola lingkungan hidup secara lestari. Dapat disimpulkan sebagai nilainilai atau aturan-aturan yang telah disepakati pada kehidupan masyarakat tertentu, menjadikan ciri khas pada daerah tersebut, dimana tujuannya adalah terkait dengan pelestarian alam sekitar. Pandangan ini hampir sepaham dengan pendapat Dokhi, dkk (PDSPK Kemdikbud RI 2016: 13), yang mengatakan bahwa kearifan lokal merupakan filosofi dan pandangan hidup yang diwujudkan dalam berbagai bidang kehidupan seperti dalam tata nilai sosial ekonomi, arsitektur, kesehatan, tata lingkungan, dan sebagainya.

Sedangkan Grenier (1998) berpendapat bahwa,Indigenous Knowledge adalah pengetahuan lokal tradisional yang memiliki sebuah keunikan, 
yang berkembang di kelompok wanita dan pria asli tertentu di suatu wilayah geografis tertentu. Hal ini mencakup semua aspek kehidupan, termasuk pengelolaan lingkungan alam, telah terbukti mampu menjadikan masyarakat yang mengembangkannya tetap bertahan hidup. Jika dilihat dari sifatnya,indigenous knowledge bersifat dinamis, dan dapat beradaptasi dengan sistem pengetahuan dan teknologi dari luar yang selalu berkembang.

Menurut Laksmi (2007: 185-187), indigenous knowledge merupakan seperangkat simbol kolektif yang diwariskan oleh generasi-generasi sebelumnya dari kolektivitas pemilik simbol tersebut. Beliau menyebutkan juga bahwa indigenous knowledge pada dasarnya bersumber dari pengetahuan kolektif suatu masyarakatyang diperoleh melalui proses "pembelajaran" secara turun temurun.

\section{Identitas Nasional}

Dalam buku ajar Pendidikan Kewarganegaraan untuk Perguruan Tinggi (2016), disebutkan bahwa identitas nasional merupakan jati diri yakni ciri-ciri atau karakeristik, perasaan atau keyakinan tentang kebangsaan yang membedakan bangsa Indonesia dengan bangsa lain.

Hidayat (2009: 18) mengartikan identitas nasional sebagai ungkapan nilai-nilai budaya suatu bangsa yang bersifat khas dan membedakan dengan bangsa lain. Adapun unsur pembentuk identitas nasional antara lain: sejarah, kebudayaan, suku bangsa, agama dan bahasa. Sehubungan dengan kebudayaan, aspek kebudayaan yang menjadi unsur pembentuk identitas nasional adalah akal budi, peradaban dan pengetahuan.

\section{Perpustakaan Digital}

\section{Perpustakaan}

Dalam bukunya, Basuki (1991) menyebutkan bahwa perpustakaan diartikan sebuah ruangan atau gedung yang digunakan untuk menyimpan buku dan terbitan lainnya yang biasanya disimpan menurut tata susunan tertentu yang digunakan pembaca bukan untuk dijual.Sutarno (2006: 11), 
lebih dalam merinci mengenai arti perpustakaan sebagai suatu ruangan, bagian dari gedung/ bangunan atau gedung tersendiri yang berisi buku-buku koleksi yang disusun dan diatur demikian rupa, sehingga mudah untuk dicari dan dipergunakan apabila sewaktu-waktu diperlukan oleh pembaca.

Sedangkan jika mengacu pada tujuan perpustakaan umum menurut UNESCO tahun 1972 adalah:

- Memberikan kesempatan bagi kalayak umum untuk membaca bahan pustaka yang dapat membantu meningkatkan kearah kehidupan yang layak

- Sebagai penyedia sumber informasi yang cepat, tepat dan murah bagi masyarakat

- Mengembangkan kemampuan masyarakat melalui bahan pustaka

- Sebagai agen kultural atau pusat utama kehidupan budaya dengan menumbuhkan apresiasi budaya pada masyarakat.

\section{Digital}

Supriyanto (2008) berpendapat bahwa, produk digital merupakan hasil dari sebuah proses perubahan dari dokumen tercetak menjadi dokumen elektronik. Format yang biasa digunakan antara lain: html, PDF, Microsoft Word, Microsoft Excel, jpeg, GIF,dsb (Saleh, 2010).Wikipedia mendefinisikan digital merupakan penggambaran dari suatu keadaan bilangan yang terdiri dari angka 0 dan 1 atau off dan on (bilangan biner).Sedangkan dalam KBBI Digital berhubungan dengan angka-angka untuk sistem perhitungan tertentu; berhubungan dengan penomoran.

\section{Perpustakaan Digital}

Perpustakaan Digital adalah penerapan teknologi informasi sebagai sarana untuk menyimpan, mendapatkan, dan menyebarluaskan informasi ilmu pengetahuan dalam format digital.Atau secara sederhana dapat dianalogikan sebagai tempat menyimpan koleksi perpustakaan yang sudah dalam bentuk digital. (Subrata, 2009) 
Sedangkan menurut Sutton (1996) dalam Sudarsono, perpustakaan digital merupakan jenis perpustakaan masa depan tanpa dinding yang memberikan akses pada referensi atas sumberdaya informasi digital di berbagai lokasi. Supriyanto (2008: 31) mendefinisikan perpustakaan sebagai sebuah sistem yang memiliki berbagai layanan dan obyek informasi yang mendukung akses objek informasi tersebut melalui perangkat digital. Menurut Supriyanto perpustakaan digital sama dengan perpustakaan biasa tetapi prosedur kerjanya berbasis komputer dan sumber informasinya digital.

Menurut Saleh (2010: 3), menyebutkan bahwa perpustakaan digital adalah organisasi yang menyediakan sumber-sumber dan staf ahli untuk menyeleksi, menyusun, menyediakan akses, menerjemahkan, menyebarkan, memelihara kesatuan dan mempertahankan kesinambungan koleksi-koleksi dalam format digital sehingga selalu tersedia dan murah untuk digunakan oleh komunitas tertentu dan ditentukan. Lebih dalam lagi beliau mengatakan bahwa koleksi tidak terbatas pada dokumen elektronik pengganti bentuk tercetak saja, ruang lingkup koleksinya sampai pada artefak digital, yang tidak tergantikan oleh bentuk tercetak.

Sutarno (2006: 62), menyebutkan bahwa perpustakaan digital merupakan perpustakaan yang mengembangankan sistem pengelolaan dan sistem layanannya dengan memanfaatkan teknologi informasi.Senada dengan Supsiloani(2006), menyebutkan bahwa perpustakaan digital merupakan penerapan teknologi informasi dalam perpustakaan sebagai saranauntuk menyimpan, mendapatkan dan menyebarluaskan informasi ilmupengetahuan dalam format digital.

\section{Pembahasan}

"Merawat dan menjaga kearifan lokal budaya itu sangat penting sekali karena intervensi peradaban barat dan peradaban negara lain itu sangat terus mendesak kita," ujar Presiden Jokowi.

Penggalan kalimat dari bapak Presiden diatas seakan menyadarkan kita tentang terancamnya kearifan lokal yang Indonesia miliki.Jika diamati, 
Indonesia merupakan negara yang dikenal sebagai negara yang besar dengan potensi budaya yang beraneka ragam, yang tersebar dari sabang sampai merauke.Laksmi (2007: 185), mengatakan bahwa kearifan lokal (indigenous knowledge) dapat digolongkan ke dalam budaya tak benda, atau budaya yang tidak berwujud benda (intangible culture) yang bersifat abstrak, seperti konsep dan teknologi, musik, tari ritual dan perilaku terstruktur lainnya. Kearifan lokal merupakan bagian dari budayasuatu masyarakatyang tidak dapat dipisahkan dari bahasa masyarakat itu sendiri.Dari data yang diperoleh, Indonesia memiliki sekitar 17.504 pulau, lebih dari 700 suku bangsa/etnis, serta memiliki sekitar 583 bahasa daerah atau dialek.(Zelth, D. Kearifan Lokal: Aset Besar Bangsa Indonesia,2017.

Dengan kekayaan budaya yang begitu besar tentunya hal ini juga menyadarkan kita bahwa Indonesia juga memiliki potensi kearifan lokal yang tentunya sangat besar.Meliono (2011), mengatakan bahwa secara langsung atau tidak langsung, budaya memberikan pengaruh pada pembentukan kearifan lokal.Tetapi ditengah potensi kearifan lokal sebagai harta kekayaan bangsa Indonesia, disisi lain peradaban dan pengaruh dari luar negeri juga ikut mempengaruhi potensi kearifan lokal yang kita miliki. Kearifan lokal yang seharusnya dilestarikan dan dijaga, sejalan dengan perkembangan teknologi dan pengaruh budaya luar, mulai mengalami degradasi.Pernyataan ini diperkuat oleh Dokhin dkk (2016) yang menyatakan bahwa arus globalisasi yang deras menawarkan gaya hidup yang cenderung pragmatis serta bergaya hidup konsumtif terbukti secara perlahan-lahan telah mereduksi nilai-nilai yang diajarkan dalam kearifan lokal. Jika diamati, hal ini dapat kita lihat dengan mulai tidak tertariknya generasi muda sekarang dengan seni budaya asli Indonesia seperti wayang, ludruk, seni tari, silat,dsb. Hal ini diindikasi karena generasi sekarang lebih banyak larut dengan kemajuan teknologi, sehingga melupakan kearifan lokal yang seharusnya dipelihara dan diturunkan dari generasi ke generasi. Selain itu, menurunnya kesadaran dari pihak orangtua untuk mengenalkan budaya asli Indonesia kepada generasi penerusnya (anak) juga menjadi salah satu penyebab telah mereduksinya nilai-nilai yang diajarkan dalam kearifan lokal. Jika diamati, 
pada masa sekarang orangtua cenderung memperlengkapi dan mengajarkan bagaimana menggunakan teknologi yang canggih dibanding mengenalkan nilai-nilai budaya asli Indonesia sejak dini.

Dalam sambutan Presiden RI masa kepemimpinan Susilo Bambang Yudhoyono,pada Pencanangan Gerakan Pemberdayaan Perpustakaan di Masyarakat di Jakarta, 17 Mei 2006 yang lalu diakses tanggal 24 Agustus 2017), mengatakan bahwa naskah-naskah yang ditulis berabad-abad yang lalu pada daun lontar, kulit kayu dan tulang, menunjukkan bahwa nenek moyang kita dulu telah memberikan teladan dalam budaya menulis dan membaca. Hal ini menunjukkan bahwa sebenarnya kearifan lokal begitu penting untuk diturunkan dari generasi kegenerasi berikutnya sebagai warisan budaya. Warisan budaya inilah yang mampu mempertahankan identitas nasional bangsa Indonesia.

Herdiawanto dan Jumanta (2010), berpendapat bahwa identitas nasional Indonesia merujuk pada suatu bangsa yang majemuk. Kemajemukan tersebut merupakan gabungan dari unsur-unsur pembentuk identitas, yaitu: 1. Suku bangsa, merupakan golongan sosial yang khusus yang bersifat askriptif, yang sama coraknya dengan golongan umur dan jenis kelamin.

2. Agama, merupakan keyakinan yang dianut oleh seseorang terhadap penciptanya.

3. Bahasa, merupakan sistem perlambangan yang secara arbiter dibentuk atas unsur-unsur bunyi ucapan manusia, dan digunakan sebagai sarana berinteraksi antara manusia.

4. Kebudayaan, diartikan sebagai pengetahuan manusia sebagai makhluk sosial yang isinya adalah perangkat atau model pengetahuan yang secara kolektif digunakan oleh pendukung-pendukungnya untuk menafsirkan dan memahami lingkungan yang dihadapi dan digunakan sebagai rujukan atau pedoman untuk bertindak (dalam bentuk kelakukan dan bendabenda kebudayaan) sesuai dengan lingkungan yang dihadapi.

Bakry (2011: 101) mengatakan bahwa kebudayaan daerah merupakan kerangka dasar yang saling berintegrasi menuju kesatuan kebudayaan 
nasional.Dan kebudayaan nasional tersebut merupakan "identitas nasional dan menjadi kebanggan bangsa.Penulis dapat menyimpulkan bahwa dengan terintegrasinya (penyatuan) kebudayaan daerah, hal ini dimungkinkan dapat mempertahankan serta memperkuat identitas nasional bangsa Indonesia. Dalam upaya mewujudkan penyatuan budaya ini, pemerintah tentunya membutuhkan wadahnya. Dalam Undang-undang Nomor 43 Tahun 2007, secara rinci fungi perpustakaan yang berorientasi pada warisan budaya adalah sebagai berikut:

a. Akuisisi, pelestarian, dan perekaman bibliografis atas materi yang muncul dari atau tentang negara sendiri.

b. Akses dokumen baik langsung atau jarak jauh pada akumulasi koleksi.

c. Jasa referensi atau informasi, termasuk penyusunan petunjuk koleksi warisan budaya nasional.

d. Pelaksanaan pelatihan kerja bagi pustakawan setempat.

e. Pelaksanaan penelitian dan pengembangan terkait dengan koleksi, sistem dan sebagainya.

Dari penjelasan diatas, dapat dilihat bahwa perpustakaan nasional memiliki tanggung jawab dalam melakukan akuisisi, melestarikan, memberikan akses, memberikan informasi dan petunjuk terhadap warisan budaya nasional. Tetapi ditengah gencarnya kemajuan teknologi informasi seperti sekarang ini, tentunya banyak tantangan yang dihadapi oleh perpustakaan nasional dalam upayanya memperkenalkan, memberikan akses, memberikan informasi terkait dengan warisan budaya Indonesia ke generasi berikutnya.Faktor-faktor hambatan tersebut dapat berasal dari dalam (internal) atau pun dari luar (eksternal). Faktor dari dalam (internal) dimungkinkan karena keterbatasan sumber daya manusia yang dimiliki, sumber dana, ide pengembangan,dsb. Sedangkan hambatan dari luar (eksternal) dimungkin dapat terjadi karena kurang tertariknya generasi saat ini dengan warisan budaya Indonesia, pengaruh perkembangan teknologi, juga kesadaran orangtua/ generasi pendahulu untuk menurunkan warisan budaya/ kearifan lokal nya ke generasi berikutnya.Oleh karena itu, pada 
uraian berikutnya penulis berupaya untuk menuliskan beberapa ide dari manifestasi perpustakaan nasional untuk menghadapi hambatan-hambatan yang ada, baik internal maupun eksternal.

\section{Manifestasi Perpustakaan Nasional dalam melestarikan Indegenous Knowledge}

Melihat adanya beberapa hambatan baik internal maupun eksternal, seharusnya tidak menyurutkan kita untuk tetap melestarikan kearifan lokal yang dimiliki bangsa kita. Pendekatan yang dapat dilakukan adalah melalui pendekatan dalam perpustakaan tradisional dan perpustakaan digital. Manifestasi dalam perpustakaan nasional sebagai berikut:

\section{- Pendekatan Teknologi dalam Perpustakaan}

Suwarno (2011: 29), mengatakan bahwa perpustakaan sebagai tempat pengembangan kebudayaan melalui penanaman nilai-nilai kepada masyarakat melalui berbagai kegiatan, seperti pemutaran film dokumenter, belajar menari, les bahasa, story telling, dsb. Hal ini senada dengan salah satu fungsi perpustakaan sebagai "rekreasi kultural" (Purwono dan Sri, 2013: 1.6). Tetapi diera kemajuan teknologi seperti saat ini dibutuhkan terobosan yang lebih inovatif sehingga mampu menarik perhatian generasi muda, oleh karena itu penulis mengembangkan ide agar perpustakaan nasional mengembangkan teknologi augmented reality. Menurut Ronald T. Azuma, augmented reality atau realitas tertambah merupakan penggabungan bendabenda nyata dan maya dilingkungan nyata, berjalan secara interaktif dalam waktu nyata, dan terdapat integrasi antar benda dalam tiga dimensi, yaitu benda maya terintegrasi dalam dunia nyata.

Salah satu aplikasi nyata dari penerapan teknologi ini adalah mengkombinasikan sistem pencari informasi (OPAC) dengan teknologi augmented reality. Jika teknologi OPAC saat ini dijalankan melalui komputer yang menetap, dalam pengembangan teknologi ini pencarian buku dapat dilakukan melalui tablet, android atau smartphone yang telah terpasang aplikasi augmented reality. Secara lebih jelas akan ditampilkan pada gambar berikut: 


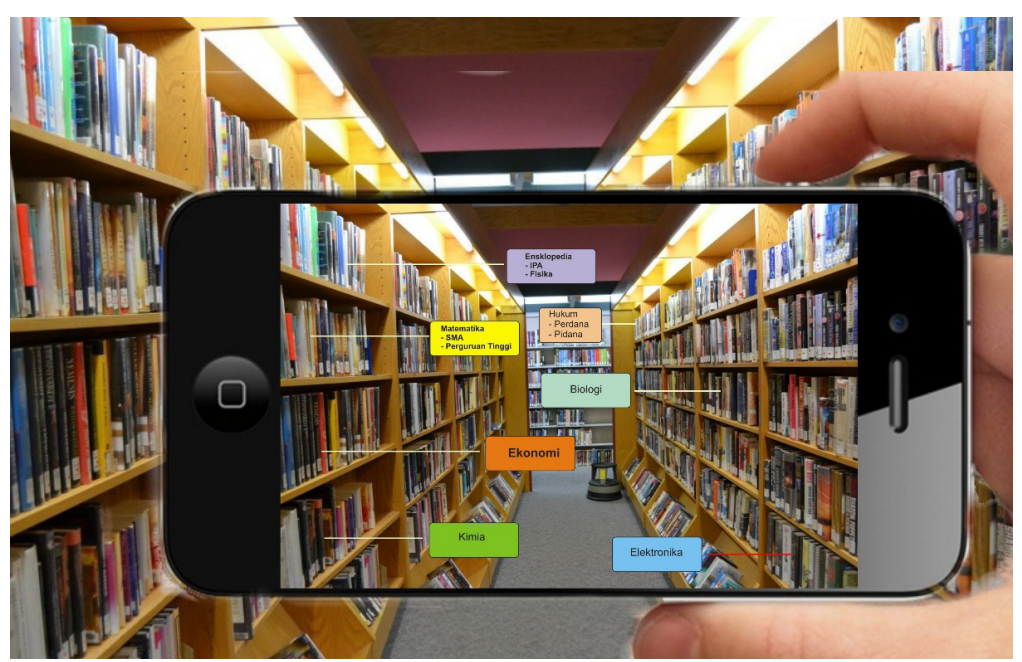

Gambar 1. Contoh Teknologi Augmented Reality

(diolah kembali dari berbagai sumber)

Selain itu., perpustakaan juga dapat mengkombinasikan perpustakaan digital dengan teknologi "virtual reality" (VR). Virtual reality" (VR) atau realitas maya menurut definisi wikipedia adalah, teknologi yang membuat pengguna dapat berinteraksi dengan suatu lingkungan yang disimulasikan oleh komputer (computer-simulated environment), suatu lingkungan sebenarnya yang ditiru atau benar-benar suatu lingkungan yang hanya ada dalam imaginasi. Dalam mengaplikasikan teknologi virtual reality, dibutuhkan sebuah perangkat khusus yaitu headset VR (virtual reality). Dalam penerapannya, penelusuran terhadap koleksi digital dapat dikondisikan seperti petualangan 3D melalui headset VR yang dipakai sehingga pustakawan yang menelusur koleksi perpustakaan digital serasa "menjelajah sendiri" dalam sebuah perpustakaan. Selain menampilkan bahan pustaka digital terkait budaya Indonesia, dimungkinkan juga ditampilkannya koleksi artefak-artefak digital sebagai suatu peninggalan kearifan lokal/ budaya lokal asli Indonesia. Dalam upaya melestarikan budaya Indonesia melalui kemajuan teknologi ini, koleksi artefak dalam bentuk digital dirasa penting dikarenakan tidak tergantikan dengan bentuk cetak (Saleh, 2010). 
Sebuah Upaya Mempertahankan Identitas Nasional: Pelestarian Indegenous Knowledge melalui Pengembangan Teknologi pada Perpustakaan Nasional

Melalui manifestasi ini diharapkan mampu memberikan warna baru bagi perpustakaan nasional baik yang sifat layanannya "tradisional" maupun digital, sehingga mampu menarik lebih banyak generasi muda untuk ikut berpetualang (rekreasi) didalam perpustakaan yang didalamnya mengkoleksi kearifan lokal tetapi dengan kemasan teknologi modern.

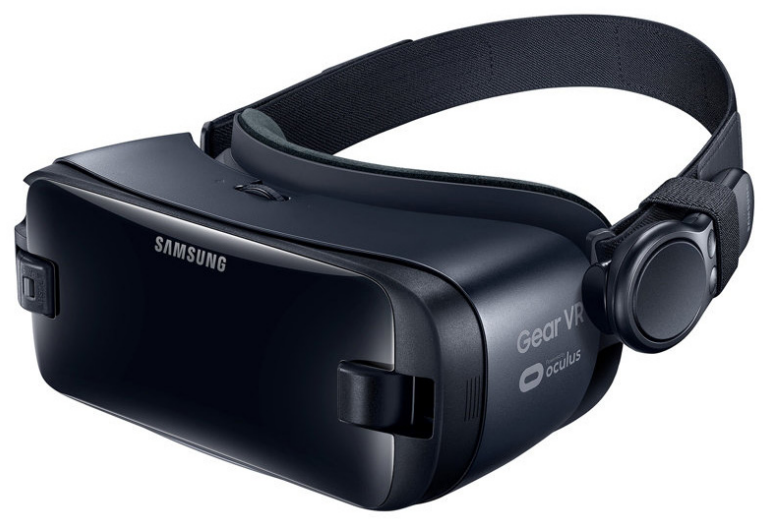

Gambar 2. Contoh Headset VR (virtual reality)

Sumber: http://www.samsung.com/us/mobile/virtual-reality/gear-vr/gear-vr-withcontroller-sm-r324nzaaxar/

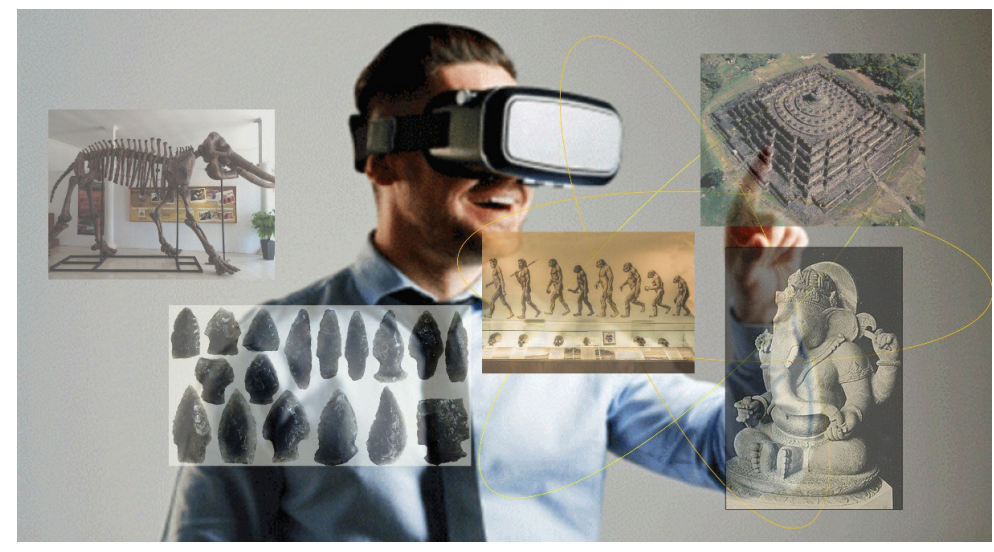

Gambar 3. Contoh Teknologi Virtual Reality

(diolah kembali dari berbagai sumber) 


\section{- Perpustakaan Digital Nasional dapat berperan sebagai Bank Repository.}

Hal ini dilakukan dengan cara, membuka hak akses untuk melakukan upload ke sistem perpustakaan digital (Nasional) terhadap karya dari masyarakat seperti karya etnografis (audio, video, tulisan) yang terkait dengan kearifan lokal Indonesia. Karena keterbatasan sumber daya manusia yang dimiliki perpustakaan nasional, oleh karena itu dibutuhkan sukarelawan, peneliti, maupun pihak ketiga untuk ikut serta dalam mengkoleksi datadata terkait kearifan lokal (upload) yang tetap "dikelola” oleh Perpustakaan Nasional. Purwono (2013: 2.39), menamakan pihak-pihak tersebut sebagai mitra perpustakaan atau dalam istilah asingnya friends of the library. Mitra perpustakaan di definisikan sebagai berbagai pihak, baik pemerintah maupum swasta yang merasa ikut bertanggung jawab dan terpanggil dalam program-program di bidang pengembangan perpustakaan, mencerdaskan masyarakat, dan masyarakat yang gemar membaca.

\section{- Resource Sharing}

Integrasi perpustakaan digital yang berada didaerah (Perpusda) melalui resource sharing khususnya terkait dengan potensi-potensi kearifan lokal yang dimiliki oleh daerah tersebut. Resource sharing atau pemakai bersama bahan pustaka yang terintegrasi antara perpustakan digital (nasional) dengan perpustakaan digital daerah akan saling memperkaya dan melengkapi koleksi-koleksi yang terkait dengan kearifan lokal dan budaya Indonesia. Resource sharing atau pemakai bersama ini juga merupakan salah satu fungsi perpustakaan nasional dalam hal manajemen koleksi khususnya melaksanakan pertukaran bahan pustaka secara nasional (Purwono, 2013: 2.6)

Melalui pemakaian bersama ini dirasa mampu mengatasi hambatan yang terkait dengan pengadaan koleksi, dana pengadaan koleksi, keterbatasan sumberdaya, dsb.

Dampak pelestarian indegenous knowledge melalui perpustakaan digital (nasional) terhadap identitas nasional

1. Terintegrasinya perpustakaan digital secara nasional tersebut maka secara otomatis akan memperkuat indentitas nasional yang dimiliki bangsa 
Indonesia. Setiap orang dapat mengenal Indentitas Nasional yang ber Bhineka Tunggal Ika khususnya kearifan lokal / budaya lokal Indonesia dengan informasi yang lebih lengkap, cepat akses serta terupdate dengan lebih baik melalui jaringan internet.

2. Dipublikasikannya kearifan lokal dan kebudayaan lokal Indonesia melalui perpustakaan digital nasional, ini artinya menuntut diakuinya kebudayaan yang dimiliki Indonesia yang mungkin belum dikenal oleh dunia internasional. Dengan diakuinya kearifan lokal/ kebudayaan Indonesia tersebut, hal ini dapat mengantisipasi diklaimnya budayabudaya Indonesia oleh negara lain. Dalam hal ini, ancaman terhadap Identitas Nasional dapat diminimalkan atau dengan kata lain dengan diakuinya kearifan lokan/ kebudayaan Indonesia maka Indentitas Nasional akantetap dipertahankan dan semakin kuat.

3. Dengan dilestarikannya kearifan lokal melalui perpustakaan digital, artinya Indonesia mempunyai dokumen nasional yang sah mengenai kearifan lokal Indonesia. Belajar dari kasus pulau Ambalat, dimana Malaysia dalam kasus tersebut menang atas gugatannya terhadap Indonesia, hal tersebut dikarenakan Malaysia memiliki dokumendokumen yang sah terkait pulau Ambalat. Dengan dikoleksinya informasi mengenai kearifan lokal dalam perpustakaan digital nasional, hal ini sama dengan Indonesia memiliki dokumen yang sah terkait budaya asli Indonesia, tentunya hal ini dapat menjadi keuntungan tersendiri bagi Indonesia ketika harus menghadapi klaim dari negara lain. Dengan dimilikinya dokumen terkait kekayaan budaya Indonesia, pastinya akan lebih kuat secara hukum, sehingga hal ini akan lebih memperkuat bangsa Indonesia dalam mempertahankan identitas nasional agar tidak direbut pihak lain

4. Memaksimalkan fungsi perpustakaan nasional sebagai agen kultural (Purwono, 2013: 1.9). Melalui perpustakaan digital nasional yang memiliki jangkauan lebih luas, tentunya akan lebih memaksimalkan fungsi perpustakaan dalam menumbuhkan apresiasi budaya masyarakat serta menurunkan kearifan lokal/ budaya lokal ke generasi berikutnya. 
Perpustakaan digital merupakan bentuk kemajuan teknologi yang diharapkan dapat digunakan untuk mengatasi lunturnya kearifan lokal Indonesia. Karena dengan semakin luntur dan hilangnya kearifan/ budaya lokal, harus disadari juga akan semakin hilangnya identitas yang dimiliki bangsa Indonesia, yang dikenal dengan kekayaan budayanya. Hal ini senada dengan Sutarno (2006: 69), perpustakaan merupakan agen perubahan, agen pembangunan, dan agen kebudayaan umat manusia. Sebab berbagai penemuan, sejarah, pemikiran dan ilmu pengetahuan yang telah ditemukan pada masa lalu, yang direkam dalam bentuk tulisan atau dalam bentuk tertentu yang disimpan dalam perpustakaan. Koleksi tersebut dapat dipelajari, diteliti, dikaji, dan dikembangkan oleh generasi sekarang dan digunakan sebagai landasan penuntun untuk merencanakan masa depan yang lebih baik.

\section{Kesimpulan}

1. Melestarikan warisan bangsa yang memiliki budaya yang ber Bhineka Tunggal Ika adalah usaha untuk mempertahankan sebuah identitas nasional sebuah bangsa.

2. Kemajuan teknologi yang disinyalir menjadi salah satu penyebab lunturnya kearifan lokal, jika diperhatikan dengan lebih seksama, hal tersebut juga dapat menjadi solusi untuk mengembalikan minat generasi muda agar tertarik terhadap kearifan lokal itu sendiri. Hal ini mungkin dapat dilakukan melalui inovasi fasilitas perpustakaan yang dikemas dalam bentuk 3D grafis didukung dengan sistem canggih seperti augmented reality dan virtual reality.

3. Semakin hilangnya kearifan lokal yang dimiliki sebuah bangsa, sama dengan hilangnya identitas nasional bangsa tersebut. Bangsa Indonesia merupakan bangsa yang dikenal dengan budayanya sebagai sebuah identitas nasional. Perpustakaan nasional menjadi salah satu usaha untuk melestarikan dan mengenalkan kearifan lokal dan budaya bangsa kepada generasi penerusnya. Perkembangan perpustakaan telah sampai pada masa digital, sehingga perpustakaan nasional dituntut untuk lebih inovatif 
dalam mengelola perpustakaan digitalnya yang merupakan aset bangsa Indonesia dalam melestarikan budaya bangsa termasuk didalamnya kearifan lokal.

\section{Daftar Pustaka}

Azuma, Ronald, et all. 2001. "Recent Advances in Augmented Reality".IEEE Computer Graphics and Applications.

Bakry, Noor Ms. 2011. Pendidikan Kewarganegaraan. Yogyakarta: Pustaka Pelajar, cetakan ke-II.

Basuki, Sulistyo. 1991. Periodisasi Perpustakaan Indonesia. Remadja Rosdakarya. Bandung.

Dedet Zelth. Kearifan Lokal, Aset Besar Bangsa Indonesia. Diakses pada tanggal 18 Agustus 2017, di http://Dedetzelth.Blogspot.Co.Id/2013/02/ Kearifan-Lokal-Aset-Besar-Bangsa.Html.Diakses tgl 18 Agustus 2017

Direktorat Jenderal Pembelajaran dan Kemahasiswaan Kementerian Riset, Teknologi, dan Pendidikan Tinggi Republik Indonesia. 2016. Buku Ajar Mata Kuliah Wajib Umum Pendidikan Kewarganegaraan.

Dokhin, dkk.2016. Analisis Kearifan Lokal ditinjau dari Keragaman Budaya Tahun 2016.Pusat Data dan Statistik Pendidikan dan Kebudayaan (PDSPK) Kementerian Pendidikan dan Kebudayaan Republik Indonesia.

Herdiawanto dan Juwanta. 2010. Cerdas, Kritis, dan Aktif Berwarganegara:

Pendidikan Kewarganegaraan untuk Perguruan Tinggi. Jakarta: Erlangga.

Hidayat, Komaruddin dan Azyumardi Azra. 2009. Pendidikan Kewargaan:

Demokrasi, Hak Asasi Manusia, dan Masyarakat Madani. ICCE UIN Hidayahtullah \& Prenada Media Group, Jakarta

Louise Grenier. 1998. Working with Indigenous Knowledge: A Guide for Researchers. Ottawa: IDRC.

Laksmi.2007. Tinjauan Kultural terhadap Kepustakawanan (Inspirasi dari Sebuah Karya Umberto Eco). Jakarta: CV. Agung Seto. 
Meliono,I.2011. Understanding the Nusantara Thought and Local Wisdom as an Aspect of the Indonesian Education. International Journal for Historical Studies, vol. 2(2), page 221-234.

Purwono dan Sri Suharmi W. 2013.Perpustakaan dan Kepustakawanan Indonesia. Jakarta: Penerbit: Universitas Indonesia.

------Realitas Maya. diakses tanggal 28 Agustus 2017, di https://id.wikipedia. org/wiki/Realitas_maya

Saleh, Abdul Rahman. 2010. Membangun Perpustakaan Digital. Jakarta: Sagung Seto.

Subrata, Gatot. 2009. Perpustakaan Digital. Artikel Pustakawan Universitas Negeri Malang.

Suwarno, Wiji. Dasar-dasar Ilmu Perpustakaan (Sebuah Pendekatan Praktis).2007. Yogyakarta: Ar-Ruzz Media.

Sudarsono, Blasius. 2006. Antopologi Kepustakawanan Indonesia. Jakarta: Sagung Seto.

Supriyanto, Wahyu dan Ahmad Muhsin. 2008. Teknologi Informasi

Perpustakaan: Strategi Perancangan Perpustakaan Digital. Yogyakarta:

Penerbit Kanisius.

Sutarno, NS. 2006. Perpustakaan dan Masyarakat. Jakarta: CV Sagung Seto. Supsiloani. 2006. Perpustakaan Digital sebagai Wujud Penerapan Teknologi Informasi di Perguruan Tinggi. Pustaha: Jurnal Studi Perpustakaan dan Informasi, Vol.2, No.1, Juni 2006

Suwarna, Wiji. 2011. Perpustakaan dan Buku: Wacana Penulisan \& Penerbitan. Yogyakarta: Ar-Ruzz Media.

---Undang-undang Nomor 43 Tahun 2007. Diakses tanggal 20 Agustus 2017, di http://htl.unhas.ac.id/form_peraturan/photo/094607UU\%20No.43\%20tahun\%202007\%20tentang\%20Perpustakaan.pdf. --UU Nomor 32 Tahun 2009 Tentang Perlindungan dan Pengelolaan Lingkungan Hidup diakses tanggal 24 Agustus 2017, di http://175.184.234.138/p3es/uploads/unduhan/UU_32_ Tahun_2009_(PPLH).pdf. 
Yuliani Erni. 2013. Perpustakaan Zaman Dahulu. Diakses tanggal 24 Agustus 2017, di http://warunginfos.blogspot.co.id/2012/05/perpustakaanzaman-dahulu.html.

-,2017. Diakses tanggal 12 Agustus 2017, di https://news.okezone. $\mathrm{com} / \mathrm{read} / 2017 / 07 / 30 / 338 / 1746542 /$ jokowi-jaga-kearifan-lokalsangat-penting-karena-intervensi-barat-terus-mendesak.

---------2017. Perpustakaan Digital, diakses tanggal 18 Agustus 2017, di https://id.wikipedia.org/wiki/Digital.

--------2017. Digital, diakses di https://kbbi.web.id/digital

--------,2017. Kearifan Lokal, diakses di https://id.wikipedia.org/wiki/ Kearifan_lokal 